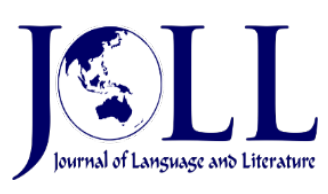

Vol. 21 No. 2, October 2021, pp. 418-428

DOI: 10.24071/joll.v21i2.3379

Available at https://e-journal.usd.ac.id/index.php/JOLL/index

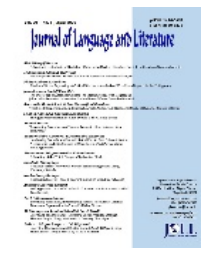

This work is licensed under a Creative Commons Attribution-ShareAlike 4.0 International License.

\title{
Diphthongized Monophthongs of Acehnese Oral Vowels in Samatiga Dialect
}

\author{
Tanzir Masykar ${ }^{1}$, Abdullah Almulhim² ${ }^{2}$ Febri Nurrahmi ${ }^{3}$ \\ febri.nurrahmi@unsyiah.ac.id \\ ${ }^{1}$ Akademi Komunitas Negeri Aceh Barat, INDONESIA \\ 2Department of English Language, King Faisal University, SAUDI ARABIA \\ ${ }^{3}$ Department of Communication, Syiah Kuala University, INDONESIA
}

\begin{abstract}
Diphthongs have been reported as the character of old Acehnese, which is now eroded in some words of modern Acehnese. However, some dialects, such as Daya and Pidie, still retain certain diphthongs in certain Acehnese words. Samatiga dialect is one of the dialects in Aceh Barat. People in Aceh Barat has commonly marked this dialect as producing certain vowel as diphthong similar to those in Teunom and Daya. Thus, the current study aims to explore the diphthongization of certain monophthong in Acehnese words by the people in Samatiga. Specifically, it aims to learn the diphthongized monophthongs in this dialect, the position in which the diphthong occurs, and the movement trajectory of the diphthong. Two language consultants are consulted to explore their diphthongization, and two other Acehnes are discussed to determine their diphthongization. Their production is recorded using a high-quality recorder and analyzed in Praat to obtain its formants data. The findings indicate that not all monophthongs are produced as diphthongs in the Samatiga dialect. Samatiga dialect replaces vowel / $\varepsilon /$ and $/ \mathrm{J} /$ with diphthong /ai/ and /au/. The diphthong /au/ seems unique to the Samatiga dialect since previous studies did not mention Acehnese diphthong ending in $/ \mathrm{u} /$. The diphthongization only occurs when it comes in the word-final and open syllable. The diphthong /au/trajectory movement is greater than /ai/, indicating the former, not the initial, may experience transformation into monophthong like other major dialects in Aceh.
\end{abstract}

Keywords: Acehnese diphthong; diphthongization of Acehnese; Acehnese dialect; Samatiga dialect of Acehnese

\section{Introduction}

While Acehnese dialects in the north tend to be more uniform, Acehnese dialects along the west coast of Aceh have been reported to vary considerably. They are so distinct from one another to the point that it makes communication impossible (Durie, 1985). 
Durie (1985) further argues that one would find a noticeable distinction with a walk of a few hundred kilometers in Aceh Besar district and villages along the west coast. This contrasts with Acehnese dialects in the north part of Aceh, where dialects tend to be consistent even after 200 kilometers.

On the west coast of Aceh lay several districts from Aceh Jaya near the border of Aceh Besar to Aceh Singkil, which borders Sumatra Utara. Some areas in Aceh Jaya and Aceh Barat have idiosyncratic features in that they tend to diphthongize some common Acehnese monophthongs. While diphthongs are a salient feature in old Acehnese, little is known about diphthongs in present-day Acehnese. Studies on Acehnese have been heavily focused on descriptive illustration of common Acehnese vowels (Asyik, 1987; Pillai \& Yusuf, 2012). Yusuf (2013) highlighted some variations of Acehnese found among Acehnese living in Malaysia, Kedah. However, her comparison is confined to the dialects in the north, particularly to the dialect of Pase. Pase dialect has been designated as standard references by many scholars (Asyik, 1987; Durie, 1985; Pillai \& Yusuf, 2012), while dialects in the west are only mentioned based on personal knowledge without any empirical studies being conducted (Asyik, 1987; Durie, 1985). Asyik (1987) also grouped the dialects in west Aceh into Aceh Barat and Aceh Selatan districts, which stark contrast to the rich varieties mentioned by Durie (1985).

A recent study on Acehnese in west Aceh was conducted by Zulfadhli (2015), but his study was limited only to the sociolinguistic aspect of the language. His study sought to learn how west Aceh dialects have been stigmatized and considered impolite by some Acehnese. These findings are quite surprising considering one of the west Aceh dialects in Lamno (anciently known as Daya) has been mentioned as the old Acehnese and, together with Aceh Besar dialects, were the basis of the present-day Acehnese (Durie, 1985). Durie (1985) further mentioned that during the reign of Sultan Ali Mughatsay, Acehnese spread to the regions along the north. However, he did not note the original language of the people in the northern part of Aceh prior to the expansion. Thus, it is unknown whether
Acehnese has been in the region prior to the expansion.

Diphthongs are the feature of old Acehnese, which is now eroded in the presentday Acehnese. If Daya (now known as Lamno) and Aceh Besar were the origins of Acehnese in present-day Aceh, it is not a coincidence that some people from Lamno (down the Geurute mountain) to parts of Samatiga has diphthongs on some words commonly uttered as monophthongs by other Acehnese. Thus, to confirm this assumption and to enrich the literature on Acehnese varieties, the current study aims to learn the production variation among Acehnese people on the west coast of Aceh. Particular attention is given to the diphthongized monophthongs of some words by the people in the area of Samatiga. Adjacent areas such as Arongan Lambalek and Kuala Bhee are also known to have diphthong but are believed to be different from Samatiga. However, the current study will only focus on the dialect in the Samatiga region, while the other regions are reserved for future studies. Three research questions are answered in the current research:

1. Which monophthongs are diphthongized in the Samatiga dialect of Acehnese?

2. In which position does the diphthong occur?

3. What is the quality of diphthongized monophthong in the Samatiga dialect?

\section{Acehnese Dialects}

Acehnese dialects have been reported to vary across regions in Aceh. Such variation was initially highlighted by Snock Horgronje in his 1892 article on Acehnese in Banda Aceh. Asyik (1987) has been simply divided Acehense dialects into four major dialects, Banda Aceh, Pidie, Pase, and Meulaboh. The dialect of Banda Aceh encompasses the people of Great Aceh and Sabang. Such designation may be no longer relevant in the current development. People in Banda Aceh come from various parts of Aceh and may have different dialects, or a new dialect has been formed due to dialect contact. What Asyik (1987) described as the Banda Aceh dialect represents the present-day Aceh Besar (Greater Aceh) dialect. This dialect has been described as the basis of present-day Acehnese (Durie, 1985). However, more outlanders have now lived and resided in 
Banda Aceh, making it a mix of Acehnese people from various districts.

Down to the East of Banda Aceh is what Asyik called as Pidie dialect. However, it is unclear to which dialect the people between Banda Aceh and Pidie belong. Going further down the east from Pidie, we would find what Asyik described as the Pase dialect. This dialect covers the people in the Aceh Utara and Aceh Timur. The Pase dialect has been mentioned as the standard dialect (Pillai \& Yusuf, 2012)based on the claims made in previous studies (Asyik, 1987; Durie, 1985). The claims were made based on the argument made by Durie (1985) that the dialect is "the most uniform and numerous speakers." As a result, the Pase dialect has gotten numerous attentions from previous researchers and has been heavily studied.

The dialect of Meulaboh mentioned by Asyik (1987) covers the area of Aceh Barat and Aceh Selatan. He also mentioned that most people in these areas are bilinguals in Acehnese and Jamee languages. Aceh Barat has now been expanded into four sub-districts, Aceh Jaya, Nagan Raya, Simelue, and Aceh Barat. While Simeulu speaks another local language, people in Nagan Raya, Aceh Barat, and Nagan Raya speak Acehnese. In relation to this, Durie (1985) argued that Acehnese variations are more noticeable in the area of Greater Aceh and Daya. Daya (now known as Aceh Jaya) is a relatively new district along the west coast of Aceh. It was administratively part of Aceh Barat districts and was recently expanded as an independent district. Its area spans from the top of Gunong Gurutue, bordering with Greater Aceh to Teunom, bordering with Arongan Lambalek subdistrict, Aceh Barat.

Samatiga is one of Aceh Barat subdistricts, located around Aceh Barat and Aceh Jaya border. In Aceh Barat, it has been reported that diphthongization of certain Acehnese monophthongs is prevalent in the areas around the borders to the northwest of Meulaboh. This area includes Samatiga, Arongan Lambalek, and Kuala Bhee (Woyla Sub-district). These three sub-districts are in close proximity to Aceh Jaya's sub-district, Teunom. Together with Lamno, Tenom is also well known for its unique diphthongization of certain Acehnese vowels. Thus, influence from Teunom on diphthongization is expected in Samatiga, Arongan Lambalek, and Kuala Bhee. Despite their diphthongization, people argue that dialects of these three areas are not uniform and are different from another, supporting the argument put forward by Durie (1985). Moving up further to the northwest from Teunom, some people in Lamno would pronounce certain /i/vowels as diphthong /ia/, such as in the word bing /bian/ [crab]. Another dialect in Daya. Another major Acehnese dialect is the Pidie dialect. It is characterized with the addition of /i/ for the pronunciation of the back vowel $/ \mathrm{a} /, / \mathrm{o} /$ and $/ \mathrm{u} /$ when the vowel is followed with $/ \mathrm{h} /$ in the final syllable. This dialect also replaces/w/ with $/ \mathrm{u} /$ and $/ \mathrm{u} /$ with $/ \mathrm{u} /$ when the vowel comes in the first syllable of two to threesyllable words. For a more recent study of this dialect, see Al-Harbi (2003). Even though this study does not specifically address the monophthongs, the study based its finding on the Pidie dialect.

According to Asyik (1987), the most notable feature of the Aceh Besar dialect is the diverse pronunciation of final $/ \mathrm{a} /$. It is sometimes produced as /a/, /ə/, and /əa/across various parts of Aceh Besar. Similar to Pidie, Pase, and Meulaboh dialect, some people in Aceh Besar pronounced the word mata [eye]' tika [mat]' and guda [horse] as /mata/, /tika/ and /guda/ respectively. Such pronunciation is prevalent in the area such as Montasiek, Krueng Raya, Indrapuri, Seulimum, and Lam Tamot. People in Ulee Lheue, Lhok Nga, and Samahani pronounced the final /a/ as /ə/ or /әа/. The /әа/ is often pronounced by a small number of people between Banda Aceh and Lhoknga in the word, such as hana /hanəa/ [there is not] and kaya /kayəa/ [rich]. Another distinctive feature is the pronunciation of the consonant /s/ as dental fricative $/ \theta /$. This feature is also prevalent in districts along the west coast of Aceh, such as Aceh Jaya, Aceh Barat, and Nagan Raya. However, it is not included as the Acehnese consonants of Pase dialect in Asyik (1987) and Durie (1985). However, it is expected because such a phoneme may not exist in the Pase dialect. 


\section{Acehnese Monophthongs}

Previous studies reported that Acehnese has ten monophthongs (Asyik, 1987; Durie, 1985; Pillai \& Yusuf, 2012). The ten oral monophthongs are distributed to front, mid and back vowels. The front vowel has three monophthongs /i/, /e/ and $/ \varepsilon /$ while the mid vowel has four monophthongs $/ \mathrm{m} /, / \partial /, / \Lambda /$, and $/ a /$. The rest of the monophthongs are back vowels/u/, /o/, and / /. All of the oral monophthongs consistently appear in various positions of Acehnese words. It can reside in word-initial, between consonant, in a wordfinal, and an open syllable. However, some monophthongs may be realized differently depending on the region. Their realization is often within the vowel inventories of Acehnese. Thus, for example, similar to Acehnese in Kampung Aceh in Malaysia, some Acehnese dialects might pronounce each vowel interchangeably depending on the words (Yusuf \& Pillai, 2016). The Acehnese oral monophthongs can be observed in the following Table.

Table 1. Acehnese Oral Monophthong

\begin{tabular}{l|c|c|c|}
\hline High & /i & /ul & /u/ \\
\hline High-mid & lel & /al & /ol \\
\hline Low-mid & /el & $/ N$ & $/ \mathrm{J}$ \\
\hline Low & & $/ \mathrm{d}$ &
\end{tabular}

The most obvious variations are often found in the $/ \Lambda$ / vowel. People in Aceh Barat, for example, may realize the word often pronounced as $/ \Lambda /$ by the people in the north as the vowels/ə/ and $/ \varepsilon /$. An example of such a word is the word göt /gat/ [good]. This word my pronounced as /g $\Lambda$ / /gat/ or /get/ depending on whom you talk to. Sometimes even the same person may pronounce the word inconsistently within the three possible pronunciations. In addition to oral monophthongs, Acehnese also has nasal monophthongs. Nasalization is a distinctive feature in Acehnese. All oral monophthongs have their nasal counterparts except for the high-mid vowels /e/, /ə/, and /o/. Thus, the nasal monophthongs in Acehnese are /ĩ/, / $\tilde{\varepsilon} /$,

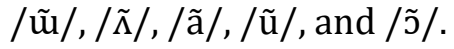

\section{Acehnese Diphthongs}

Researchers seem to disagree on the number of Acehnese diphthongs despite basing on the same dialect, the Pase dialect. According to Asyik (1987), Acehnese diphthongs are be divided into two categories, ending with /ə/and ending with /i/, while Yusuf and Pillai (2016) classified them as raising and centering diphthongs. However, even though based on the Pase dialect, Durie (1985) excluded the diphthong / $\Lambda$ / in his report. Al-Harbi (2003), who based his study on Pidie dialect, also did not include $/ \Lambda \partial /$ as Acehnese diphthongs. Thus, according to them, there are only five centering diphthongs in Acehnese. Pillai and Yusuf (2012) also found that the speakers of the Pase dialect in their study could not produce the $/ \Lambda \partial /$ diphthong as suggested by Asyik (1987). Instead of ending with /ə/, the diphthong in their studies moves closer to /u/ than /ə/. Such negative movement is also observed in the diphthong /эә/.

Table 2. Acehnese Oral Diphthong

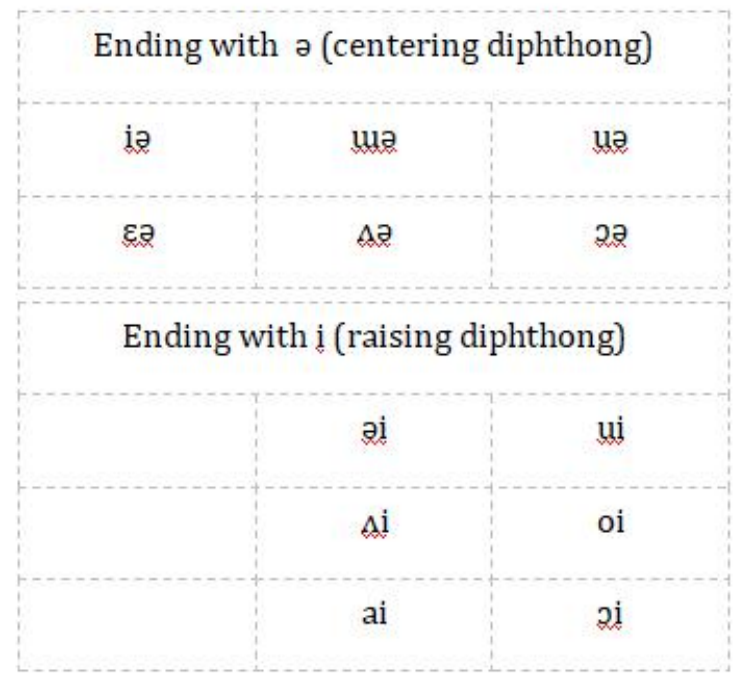

The movement of the diphthong/ $\Lambda \partial /$ to $/ \mathrm{u} /$ may indicates that there is more to Acehnese diphthongs than ending in / $/$ / and /i/. People in Samatiga, for example, have been heard to produce the back vowel /o/ as /au/. The diphthong ending with / $\mathrm{u} /$ was also mentioned in Nucifera (2018) study in words such as geujak /geudzak/ [he or she go] and deuk /deuk/ [hungry]. Another interesting diphthongization worth mentioning is the use of diphthong /ai/ in place of / эә/ by Daya dialect in Aceh Jaya (Asyik, 1987). In this 
dialect, words such as baroe /barəə/ [yesteday], taloe /taloə/ [rope] and jaroe /dzaroə/ [hand] are produced as /barai/, /talai/ and /dzarai/. Thus, we argue that diphthongs in Acehnese are dialect-specific and different across regions in Aceh.

Durie (1985) mentioned that diphthong is the feature of old Acehnese, which is eroded in the modern Acehnese. While the transition of diphthong to monophthong in the current Acehnese is almost complete, some dialects still retain certain diphthongs for certain words. Example of this the addition of /i/ to the back vowel /a/, /o/ and / $\mathrm{u}$ / in Pidie dialect. This scenario happens when the word is followed with the phoneme $/ \mathrm{h} /$ in the final syllable. The transition from diphthong to monophthong in Sileumum (part of Aceh Besar dialect) was highlighted by Durie (1985). He pointed to a daughter correcting her mother's pronunciation as evidence.

Monophthongisation was also found by Mustaqim et al. (2020) in Acehnese-Chamic lexis among the younger speakers of Acehnese at a university. They suggest that the lack of diphthong in the Acehnese word is an indication of language shift and change taking place in Aceh. Their claim is quite significant considering the diverse background of their respondents. It means this change seems universal throughout the young Acehnese generation. Instead of language change within Acehnese, Al-Auwal (2017) further argued that Acehnese had been used infrequently while Indonesian is used more commonly among friends. A similar account is also observed among the younger generation of the Acehnese community in Malaysia (Yusuf et al., 2013).

\section{Methodology}

\section{Respondents}

Two language consultants (male and female) were interviewed and recorded in the current study. Both language consultants live and are raised in Samatiga. The female consultant is an administrative staff at higher education in Aceh Barat, while the male consultant is a merchant. They both work in Meulaboh, the capital city of Aceh Barat, which is around 30 minutes drive from Samatiga.
Even though they tend to speak in Meulaboh dialects when they are in the city, back in Samatiga, they comfortably use their dialects with relatives and neighbors. They are selected based on convenient sampling and are more accessible to the researcher.

Two other native Acehnese are further consulted to assess whether the words they produce are indeed diphthongs. The consultants are not from the Samatiga region. They both live in the city of Meaulaboh and report themselves as having a non-Samatiga dialect. Thus, they can judge if their sounds are similar or different from what they commonly use. The first consultant is a male lecturer at a state Islamic university in Meulaboh, while the female consultant is a housewife. No particular considerations are given to their work background since they are selected based on a convenient sampling method.

\section{Instruments}

A set of 10 Acehnese words were asked to produce in their dialects in a carrier sentence, "Nyo lam bahasa Aceh ...." [It is in Acehnese ... ]. The words in Table 3 are used for initial assessments:

Table 3. Vowel between consonants

\begin{tabular}{|c|c|c|}
\hline $\begin{array}{c}\text { Acehnese } \\
\text { Words }\end{array}$ & $\begin{array}{c}\text { Target } \\
\text { Phoneme }\end{array}$ & $\begin{array}{c}\text { English } \\
\text { Translation }\end{array}$ \\
\hline sit & j & too, also \\
\hline pét & $\mathrm{e}$ & close eyes \\
\hline cèt & $\varepsilon$ & paint \\
\hline peut & ur & four \\
\hline tet & 2 & burn \\
\hline gòt & $\mathrm{A}$ & good \\
\hline pat & $\mathrm{a}$ & where \\
\hline & & $\begin{array}{c}\text { title for } \\
\text { Acehense } \\
\text { noble women }\end{array}$ \\
\hline cut & $\mathrm{u}$ & blow \\
\hline pot & 0 & take \\
\hline cok & 0 & \multicolumn{2}{c}{} \\
\hline
\end{tabular}

Following the initial assessment, the speakers produce words with assumed diphthongs values obtained from interviews. The words are different from the previous list because it is all in open syllables. The words in Table 4 are used to obtain the target diphthongs. 
Table 4. The vowel in the final syllable

\begin{tabular}{|c|c|c|}
\hline $\begin{array}{c}\text { Acehnese } \\
\text { Words }\end{array}$ & $\begin{array}{c}\text { Target } \\
\text { Phoneme }\end{array}$ & $\begin{array}{c}\text { English } \\
\text { Translation }\end{array}$ \\
\hline turi & i & know \\
\hline maté & $\mathrm{e}$ & dead \\
\hline bajè & $\varepsilon$ & cloth \\
\hline uleu & $\mathrm{ur}$ & snake \\
\hline rete & $\partial$ & cheap cloth \\
\hline tuxò & $\mathrm{A}$ & forget \\
\hline pula & $\mathrm{a}$ & plant (as verb) \\
\hline bahu & $\mathrm{u}$ & carry \\
\hline tulo & $\circ$ & the name of a bird \\
\hline mano & $\sim$ & take a bath \\
\hline
\end{tabular}

\section{Procedures}

At first, the Samatiga-dialect speakers were asked to produce the prepared words to see if they produced the target phonemes as diphthongs or monophthongs (Table 1). The target phoneme in these words is placed between syllables. Second, following the recording, the language consultants are further interviewed to discuss the words they usually produce as diphthongs while others tend to produce as monophthongs. Third, once an initial assumption is made about which vowels are generally produced as a diphthong, we confirm their report by pronouncing Acehnese words in which target vowels are placed in word-final and open syllables (Table 2). In both lists, the respondents are asked they are asked to produce the words in isolation in a carrier sentence. Only words produced as diphthongs are analyzed in Praat and further discussed.

\section{Data analysis}

The current study produces two types of data, speech production and written words. First, for speech production, the sounds are presented to two native Acehnese to determine whether the sounds they hear are indeed diphthongs and are different from the way they produce. Following the assessment, the F1 and F2 are measured to observe the quality of the assumed diphthongs vowel produced to see the movement trajectory of the vowels. The formula suggested by Deterding (2000) and Ling (2010) is used to measure the Rate of Change of the target vowels.
$\mathrm{F} 1_{\text {end }} \mathrm{F} 1_{\text {start }} /$ Duration (seconds) $=\mathrm{ROC}$

(Hz/second)

Where F1 is Formant 1, ROC is the rate of change, and $\mathrm{Hz}$ is Hertz. The formant 1 (F1) and formant 2 (F2) and duration are obtained through the Praat Software (Boersma \& Weenink, 2017). F1 indicates the depth of the vowel in our speech articulation, while and F2 indicates the height of the vowel (Hayward, 2000). The target word is first marked and labeled with the target phoneme. A script extracting the F1, F2, onsite and offsite time is run to the software, and values are automatically produced as a text file. To project the targetd dipthongs into the vowel space, the F1 and F2 values of each diphthongs are trnsforemd into the Bark scale as suggested by Zwicker and Terhardt (1980) and Deterding (2003).

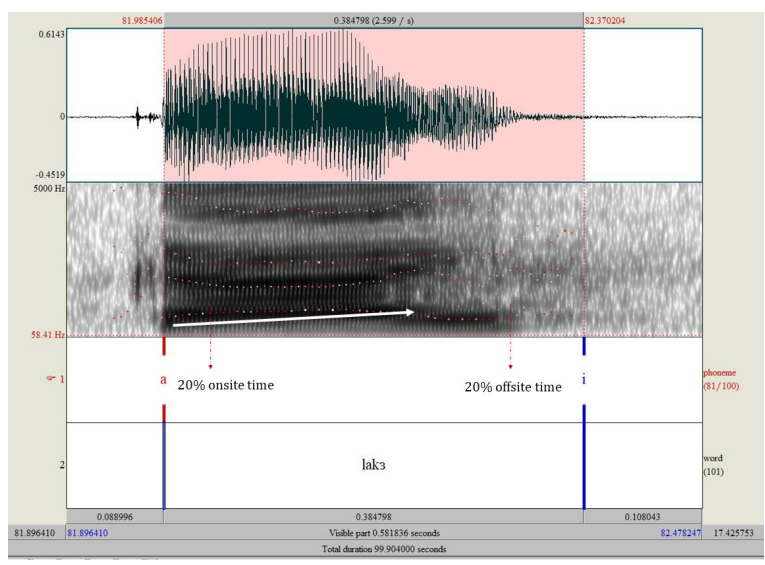

Figure 1. Measurement of the diphthong in Praat

\section{Results and Discussion}

\section{Diphthongized monophthongs in Samatiga dialects of Acehnese}

Not all Acehnese oral vowels are diphthongized by the Acehnese in Samatiga. Of eleven Acehnese oral monophthongs, the Acehnese dialect of Samatiga tends to diphthongize only on two vowels, the unrounded back vowel / $\mathrm{J} /$ and open-mid front vowel/ $\varepsilon /$. The monophthong $/ \mathrm{J} /$ is realized as $/ \mathrm{au} /$ while the vowel $/ \varepsilon /$ is produced as /ai/ in the Samatiga dialect. All other vowels are produced similar to the Acehnese dialects reported by Asyik (1987) and Pillai and Yusuf 
(2012). The changes are illustrated in the following figure 2 .

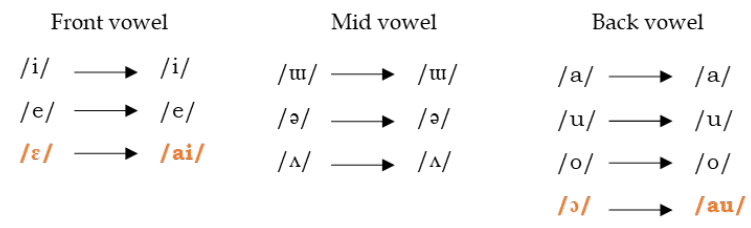

Figure 2. Acehnese vowel realized as diphthongs in Samatiga dialect

In the Samatiga dialect, the unrounded

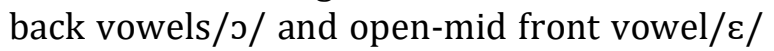
are replaced with the open front vowel $/ a$ / while the /i/ and / $\mathrm{u} /$ are respectively added to the final production. While the diphthong /ai/ is common to Acehnese diphthongs reported in Asyik (1987), Pillai and Yusuf (2012), and Nucifera (2018) studies, the diphthong /au/ is relatively foreign to other Acehnese dialects. It seems that the diphthong / $\mathrm{au} /$ is unique to Samatiga dialects. However, it is important to note that it is common for Indonesian even though /au/ is absent in other Acehnese dialects. Ones can easily find the dipthong /au/ in word final and open syllable of Indonesian word as in pulau /pulau/ [island] and galau /galau/ [confused]. Compared to Acehnese, Indonesian only has four diphthong vowels /ai/, /au/, /ei/, and /oi/. Since the people in Aceh mostly speak Acehnese and Indonesian, the diphthong /au/ is not really novel to their vowel system.

Using the framework for diphthong categories used by Yusuf and Pillai (2013), both diphthongs /au/ and /ai/ in the Samatiga dialect of Acehnese are rising diphthong. The low front vowel /a/ in diphthong /au/ for the / $\mathrm{s}$ sounds moves to the high back vowel /u/. The low front vowel /a/ in diphthong /ai/ for the $/ \varepsilon /$ sounds moves to the high front vowel /i/. This finding lends its support to the claims made in the previous study that west Aceh dialects are different from other Acehnese dialects (Asyik, 1987; Durie, 1985). Zulfadhli (2015) also found that people in West Aceh tend to produce the $/ \mathrm{r} / \mathrm{as} / \mathrm{b} /$, which is similar to one of the Arabic consonants.

\section{The position of Samatiga diphthongized monophthongs}

We initially assumed that the unrounded back vowel / / / and open-mid front vowel/ $\varepsilon /$ are produced as diphthongs in any position of Acehnese words; word-initial, word-middle, and word-final. The production of Acehnese words in Table 1 (with target vowel in the middle of the word) by the language consultant indicates that none of the vowels are produced as diphthongs. All vowels in the middle positions are produced as represented by the phonetic symbols in Table 1 . It means that when the vowel $/ \mathrm{J} /$ and $/ \varepsilon /$ occurs in between consonants, they are produced as diphthong similar to other dialects. Since Acehnese does not have diphthongs in wordinitial, we do not compare their production for Acehnese word-final. The studies by Asyik (1987) and Pillai and Yusuf (2012) also do not use word-initial of Acehnese words for Acehnese diphthongs.

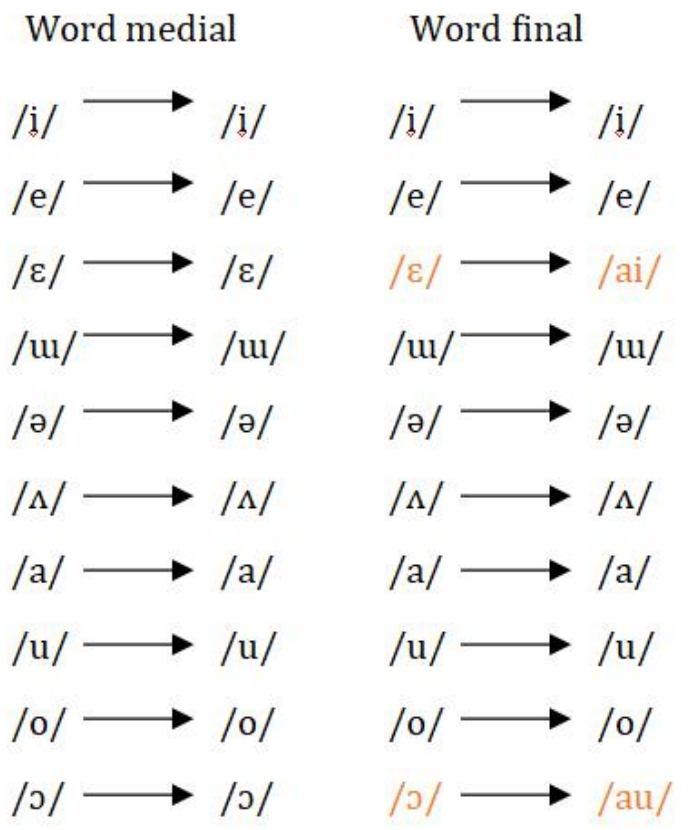

Figure 3. Vowel position in which / $\varepsilon /$ and $/ \mathrm{J} /$ are realized as diphthong

When we asked them to produce the vowels $/ \supset /$ and $/ \varepsilon /$ in various positions in Acehnese words, we learned that the $/ \mathrm{J} /$ and $/ \varepsilon /$ are diphthongized only when they come in the word-final and an open syllable. Thus, the vowel / $\mathrm{J} /$ would be produced as /au/ if it occurs in the word such as kamo /kams/ [we] and mano /mans/ [take a bath], but it will be produced as monophthong in the word such as 
cop /cэp/ [sewing] and top /top/ [prick]. Other Acehnese words in which the vowel / / are produced as /au/ can be observed in Table 5 .

Table 5. Example of words with monophthong / $/$ / realized as diphthong /au/

\begin{tabular}{|c|c|c|c|}
\hline $\begin{array}{l}\text { Acehnese } \\
\text { Word }\end{array}$ & $\begin{array}{l}\text { English } \\
\text { Translation }\end{array}$ & $\begin{array}{l}\text { Other } \\
\text { Dialect's } \\
\text { Pronunciation }\end{array}$ & $\begin{array}{l}\text { Samatiga Dialect's } \\
\text { Pronunciation }\end{array}$ \\
\hline kama & [we] & $/ \operatorname{kam} 2 /$ & / kamau/ \\
\hline baro & [yesterday] & /bas/ & /bauad/ \\
\hline mano & [take a bath] & /mana/ & /manau/ \\
\hline bune & [just now] & /many/ & /manau/ \\
\hline jino & [now] & /iing/ & / jinau/ \\
\hline kuto. & [dirty] & / kutto/ & / kutau/ \\
\hline
\end{tabular}

The vowel $/ \varepsilon /$ in Samatiga dialect are produced as diphthong /ai/ if it is in word-final and open syllable such as baje /badze/ [cloth] gute /gute/ [headbugs]. On the other hand, monophthong is maintained if it comes in between consonants such as cet / $\mathrm{t} \varepsilon \mathrm{t} /$ [paint].
In other words, Acehnese monophthong $/ \supset /$ and $/ \varepsilon /$ are diphthongized only when they are in a word-final and an open syllable. An example of word-final in open syllables produced as diphthongs /ai/ in the Samatiga dialect can be observed in Table 6 .

Table 6. Example of words with monophthong $/ \varepsilon /$ realized as diphthong /ai/

\begin{tabular}{|c|c|c|c|}
\hline Word & $\begin{array}{l}\text { English } \\
\text { Translation }\end{array}$ & $\begin{array}{l}\text { Other Dialect's } \\
\text { Pronunciation }\end{array}$ & $\begin{array}{l}\text { Samatiga Dialect's } \\
\text { Pronunciation }\end{array}$ \\
\hline bajè & [cloth] & /baje/ & /bajai/ \\
\hline malè & [shy] & $/ \mathrm{mal} /$ & /malai/ \\
\hline lakè & [ask] & /lake/ & /lakai/ \\
\hline ulè & [snake] & /ule/ & /ulai/ \\
\hline așè & [dog] & /ase/ & /asai/ \\
\hline gutè & [head bug] & /gute/ & /gutai/ \\
\hline
\end{tabular}

However, such transformation is not uniform and general as not all word-final and open syllables are produced as diphthongs in the Samatiga dialect. One example of such a word is gule /gule/ [curry]. Despite its position in the word-final and an open syllable, the vowel $/ \varepsilon /$ in the Acehnese word gule is not pronounced as diphthongs but as monophthong. We assumed such pronunciation is due to the fact that Indonesian word for curry, gulai /gulai/ is has a diphthong. Since most people in Aceh are bilingual and Indonesian and Acehnese, they may try to differentiate the Acehnese gule /gule/ with Indonesian gulai /gulai/.

Another notable exception is also observed for the word akai /akai/ [sense]. This word is commonly pronounced as diphthongs in other Acehnese dialects but is pronounced as monopthong $/ \varepsilon /$ as in /ake/ by the people in Saratoga. However, to our surprise, the word ase /ase/ [dog] is also produced as a diphthong. Ones may find it hard to distinguish the Acehnese word for the dog with another Acehnese word asai /asai/, which means 
'origin' in English unless they are uttered in context.

\section{Qualities of Samatiga diphthongized monophthongs}

In order to confirm the diphthongization of Acehnese the vowels/ว/ and / $\varepsilon /$ by Samatiga dialect, we plotted the formant values of both vowels into the vowel space as in Figure. To calculate the movement of the vowel, the Rate of Change (ROC) of each diphthong are first determined. Since the diphthong /ai/ and /au/ are both raising diphthongs (moving from low vowel /a/ to high front vowel /i/ and high back vowel /u/), only the F1 is used to determine its trajectory.

Table 7. Rate of Change (ROC) of /ai/ and /au/ diphthongs

\begin{tabular}{|c|c|c|c|c|}
\hline $\begin{array}{c}\text { Target } \\
\text { Word }\end{array}$ & $\begin{array}{c}\text { Target } \\
\text { Phoneme }\end{array}$ & $\begin{array}{c}\text { Produced } \\
\text { as }\end{array}$ & F1 ROC & F2 ROC \\
\hline lake & $/ \varepsilon /$ & $/ \mathrm{ai} /$ & -934 & 1489 \\
\hline jino & $/ \mathrm{J} /$ & $/ \mathrm{au} /$ & -1931 & -2742 \\
\hline
\end{tabular}

Table 8. F1 and F2 of /ai/ and /au/ diphthongs

\begin{tabular}{|l|l|l|l|}
\cline { 2 - 4 } \multicolumn{1}{c|}{} & Rising & F1 (Hz) & F2 (Hz) \\
\hline \multirow{2}{*}{$\begin{array}{l}\text { Onsite } \\
\text { Offsite }\end{array}$} & a & 802 & 1604 \\
\cline { 2 - 4 } & i & 573 & 1962 \\
\hline Onsite & a & 860 & 1684 \\
\hline Offsite & u & 341 & 947 \\
\hline
\end{tabular}

It is evident from the Table that both lake and jino has a greater value of F1 ROC. The F1 ROC value of jino is greater than the word lake. It means that the diphthong trajectory of /au/ is bigger than /ai/. Such more significant movement can also be observed in the Figure. The spectral illustration of the diphthong /au/ also indicates a movement nearing the end of offsite time, as in Figure 4.

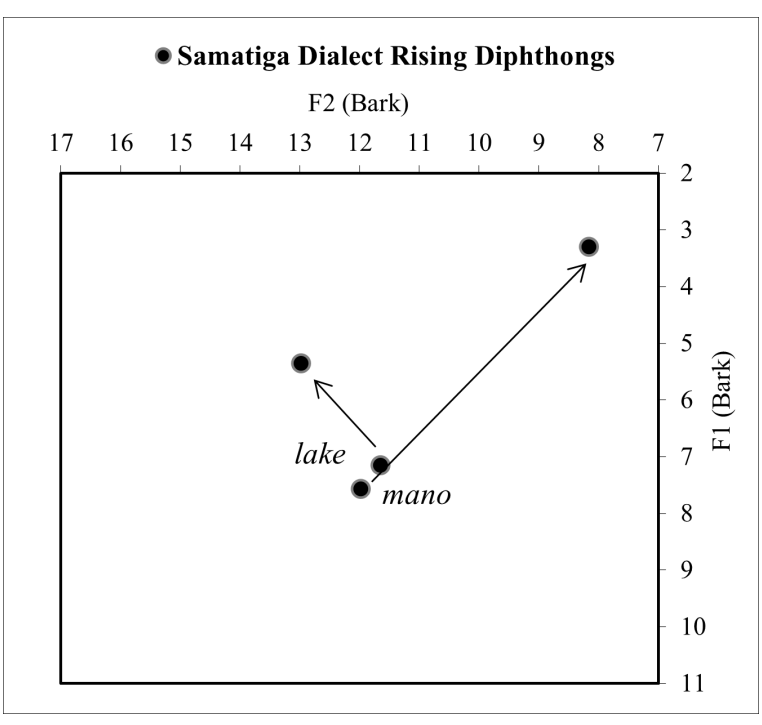

Figure 4. Trajectory movement of /ai/ and /au/ diphthongs

The rate of change for the diphthong /ai/ is also smaller than the diphthongs produced by Acehnese speakers in Pase and Kampung Aceh (Yusuf \& Pillai, 2013). ROC of the Pase and Kampung Aceh dialects was at $-1643 \mathrm{~Hz}$ and $-1607 \mathrm{~Hz}$, respectively, compared to -934 $\mathrm{Hz}$ in the current study. However, such a comparison might not be viable considering the diphthong produced in the current study is not a standard diphthong in Acehnese. The present study only looks at the words commonly produced as monophthong by most Acehnese but pronounced as a diphthong in the Samatiga dialect. Thus, it is reasonable to find that its movement may not be greater than the standard/ai/ diphthong.

The current finding is also in line with Durie (1985) argument that old Acehnese tend to produce certain words as a diphthong. If this is the case, the smaller movement in the Smatiga dialect may indicate that the diphthong is moving toward monophthong since its location is near the common position of Acehnese $/ \varepsilon /$. Comparison with equivalent words that are commonly pronounced as diphthong by Acehnese speakers, such as jai /jai/ [many] as in Asyik (1987) and Yusuf and Pillai (2013), would show how close it is produced compared to the current diphthong. 


\section{Conclusion}

This study tried to answer three research questions. The first research question sought to determine the monophthongs in which the Samatiga dialect is often pronounced as diphthongs. It was found that not all Acehnese monophthongs are pronounced as diphthongs. Of eleven Acehnese monophthongs, only the monophthongs $/ \varepsilon /$ and $/ \mathrm{J} /$ are realized as diphthongs in the Samatiga dialect. The vowel $/ \varepsilon /$ are realized as /ai/ while the vowel / $\mathrm{J} /$ is pronounced as $/ \mathrm{au} /$. Both monophthongs are first replaced with /a/ with /u/ and /i/ are respectively added.

In the second question, we later determine if the diphthongization appears in all Acehnese words containing the $/ \varepsilon /$ and $/ \mathrm{J} /$ vowel. In contrary to our initial assumption and what many non-Samatiga people believe, the diphthongization does not occur in all positions of Acehnese words. The / $\varepsilon /$ and $/ \mathrm{J} /$ is only realized as diphthongs if they occur in the final syllable. It only happens when the word is open syllable and is in the word-final position. The diphthongization does not take place if they occur in between consonants or in the word-final position. In other words, unless it occurs in the open syllable, the $/ \varepsilon /$ and $/ \mathrm{J} /$ are pronounced just the same as other major dialects in Aceh.

To answer the third question, we obtained the first and second formant values for diphthongs and analyzed their trajectory movement to determines their diphthongization. In term of quality, the diphthongs /ai/ and /au/ has trajectory movement with the negative values. However, the movement of /ai/ is smaller than the /au/, suggesting that the /ai/ maybe in the process of transitioning into monophthong as suggested by Mustaqim et al. (2020) in which the loss of diphthongs are prevalent in the younger generation. The movement of the /ai/ sound is more to the center of the vowel space, closer to the $/ \varepsilon /$ instead of $/ \mathrm{i} /$.

The current study suggests that diphthongization in Acehnese seems to be dialect-specific. Some dialects may produce certain words as diphthongs depending on their position. Even though diphthongs is the feature of old Acehnese, some dialect still retains their existence with the indication that these diphthongs are on the way to become monophthongs. Further studies should document other Acehnese dialects to gain a compressive picture of various Acehnese dialects and promote diversities in Acehnese.

\section{Acknowledgment}

This study is funded by the Ministry of Education, Culture, Research, and Technology through the Novice Lecturer Research Scheme (PDP) of 2021.

\section{References}

Al-Auwal, T. M. R. (2017). Reluctance of Acehnese youth to use Acehnese. Studies in English Language and Education, 4(1), 1-14.

Al-Harbi, A. A. A.-A. (2003). Acehnese coda condition: An optimality-theoretic account. Umm Al-Qura University Journal of Educational and Social Sciences and Humanities, 15(1), 9-28.

Asyik, A. G. (1987). A Contextual Grammar of Acehnese Sentences. University of Michigan.

Boersma, P., \& Weenink, D. (2017). Praat: Doing phonetics by computer.

Deterding, D. (2000). Measuring of the /eI/ and /əu/ vowels of young English speakers in Singapore. In D. D. A. Brown, \& E.L.Low (Ed.), The English language in Singapore: Research on pronunciation (pp. 93-99). Singapore Association for Applied Linguistics.

Deterding, D. (2003). An instrumental study of the monophthong vowels of Singapore English *. English world-wide, 1, 1-16.

Durie, M. (1985). A grammar of Acehnese on the basis of a dialect of north Aceh. 1-296.

Hayward, K. (2000). Experimental Phonetics. Longman.

Ling, L. E. (2010). English in Singapore and Malaysia. In A. Kirkpatrick (Ed.), The Routledge handbook of world Englishes (pp. 229).

Mustaqim, M., Aziz, Z. A., \& Muthalib, K. A. (2020). The Use of Acehnese-Chamic Derived Lexical Items Used by English 
Department Students of UIN Ar-Raniry. English Education Journal, 11(1), 131-162. Nucifera, P. (2018). Diftong dalam Bahasa Aceh Penelitian pada Masyarakat Penutur Asli Bahasa Aceh di Desa Meunasah Reudeup Kabupaten Bireun, Aceh. Jurnal Samudra Bahasa, 1(1), 15-22.

Pillai, S., \& Yusuf, Y. Q. (2012). An instrumental analysis of Acehnese oral vowels. Language and Linguistics, 13, 1029-1050.

Yusuf, Q., \& Pillai, S. (2013). An acoustic description of diphthongs in two varieties of acehnese. Pertanika Journal of Social Science and Humanities, 21, 153-158.

Yusuf, Y. Q. (2013). A Comparative Study of Vowels in the Acehnese Language Spoken in Kedah, Malaysia and Aceh, Indonesia [1488].

Yusuf, Y. Q., \& Pillai, S. (2016). An instrumental study of oral vowels in the Kedah variety of Acehnese. Language Sciences, 54, 14-25. https://doi.org/10.1016/j.langsci.2015.0 9.001

Yusuf, Y. Q., Pillai, S., \& Ali, N. T. A. M. (2013). Speaking Acehnese in Malaysia. Language \& Communication, 33(1), 50-60.

Zulfadhli. (2015). A Sociolinguistics Investigation of Acehnese with a focus on West Acehnese: a stigmatised dialect [1466].

Zwicker, E., \& Terhardt, E. (1980). Analytical expressions for critical-band rate and critical bandwidth as a function of frequency. The Journal of the Acoustical Society of America, 68(5), 1523-1525. 